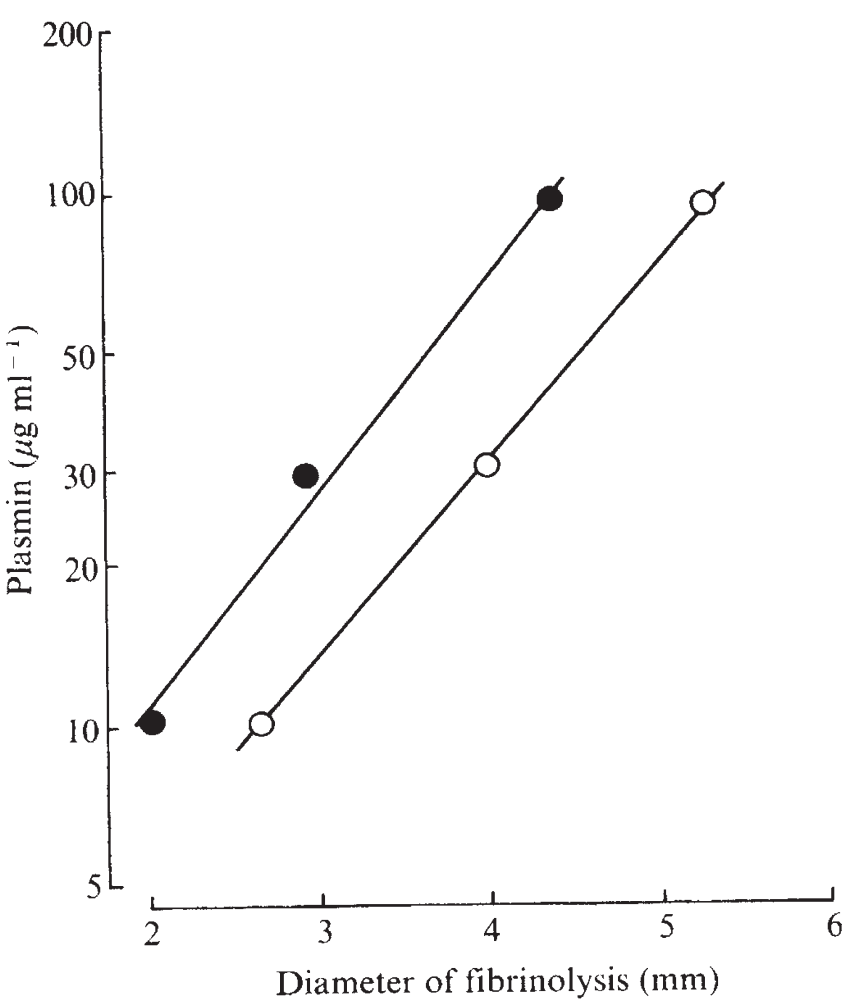

Fig. 3 Effect of vitamin $\mathbf{E}$ on lysis of fibrin by plasmin. Plasmin $\left(10,30\right.$ and $\left.100 \mu \mathrm{g} \mathrm{ml}^{-1}\right)$, with or without vitamin $\mathrm{E}\left(1.5 \times 10^{-5} \mathrm{M}\right)$ was introduced into wells $(5 \mu \mathrm{l}$ per well) of heat-treated fibrin plates (Enzo-diffusion plates, Hyland). Diameter of lysis was measured after incubation at $37^{\circ} \mathrm{C}$ for $6 \mathrm{~h}$. Semilogarithmic plot plasmin concentration against diameter of lysis, with (O) and without $(O)$ vitamin $\mathrm{E}$. Operational zero point for the assay (no detectable lysis) is $2 \mathrm{~mm}$, the diameter of the wells.

plasmin in vitro (Figs 1 and 2). Mean plasma levels of plasminogen-plasmin, determined immunochemically, are approximately $200 \mu \mathrm{g} \mathrm{ml}^{-1}$ (ref. 19). Although comprehensive data on relative proportions of proenzyme and active enzyme in normal plasma are lacking, it is generally accepted that almost all is in the proenzyme form ${ }^{20}$. In the present study, for example, plasminogen-plasmin, freshly prepared from normal plasma ${ }^{8}$, released 360 c.p.m. from ${ }^{125} \mathrm{I}$-fibrin, representing less than $2 \%$ of the activity $(18,911$ c.p.m. released) of the same preparation (enzyme concentration, $5 \mu \mathrm{g} \mathrm{ml}^{-1}$ ) after maximal urokinase activation. This estimated plasmin concentration $\left(2 \%\right.$ of $200 \mu \mathrm{g} \mathrm{ml}^{-1}$, or $\left.4 \mu \mathrm{g} \mathrm{ml}^{-1}\right)$ is of the same order as the concentrations examined here, and agrees with the observations of others ${ }^{21}$. Relative to other inhibitors, vitamin $\mathrm{E}$ produces $50 \%$ inhibition at the same concentration (approximately $10^{-5}$ $\mathrm{M})$ as EACA or tranexamic acid (trans-4-aminomethylcyclohexonecarboxylic acid $)^{8}$.

These observations may be pertinent to certain physiological and pathological phenomena, and to vitamin $E$ therapy. Plasmin is normally inhibited by anti-plasmins in plasma. These include such macromolecules as $\alpha_{2}$-macroglobulin, $\alpha_{1}$-antitrypsin and $\mathrm{Cl}$ esterase inhibitor ${ }^{22}$. The inhibition of plasmin at physiological concentrations of vitamin $\mathrm{E}$ and enzyme raises the possibility that the vitamin may play a role in normal modulation of fibrinolysis. In addition, considering the broad substrate specificity of plasmin for many tissue proteins in addition to fibrin ${ }^{5}$, this effect may be relevant to foetal resorption in vitamin $E$ deficient animals (that is, unopposed proteolytic activity), which led to the initial recognition of this vitamin ${ }^{23}$. The in vitro inhibition of plasmin provides an explanation for the reported blunting, on oral vitamin $E$ therapy, of the physiological increase in fibrinolytic activity after venous occlusion $^{7}$, a response considered to reflect increased conversion of plasminogen to plasmin, mediated by tissue activators released, presumably from vascular endothelium, in response to hypoxia ${ }^{20}$. Further, fibrinolysis has been implicated in the development and spread of tumours $\mathrm{s}^{24}$. Both EACA and vitamin E inhibit fibrinolysis. Administration of EACA decreases metastatic spread of transplantable tumours in rabbits and rats ${ }^{24}$, and there is a decreased incidence of carcinogen-induced lung tumours in vitamin E deficient mice when compared with normal mice, or deficient mice receiving vitamin $\mathrm{E}$ replacement ${ }^{25}$. Finally, in view of the widespread use of the vitamin and its succinate and acetate esters, and the observed effects of oral administration on fibrinolysis in vivo ${ }^{7}$, the observations presented here may have implications for the consequences of dietary supplementation with the vitamin.

This work was supported by grants from the MRC of Canada and the Canadian Arthritis Society.

$$
\begin{aligned}
& \text { L. A. MOROZ } \\
& \text { N. J. GILMORE }
\end{aligned}
$$

The Harry Webster Thorp Laboratories,

Division of Clinical Immunology,

McGill University Clinic,

Royal Victoria Hospital,

Montreal, Quebec, Canada H3A 1 Al

Received June 30; accepted October 27, 1975.

1 Molenaar, I., Vos, J, and Hommes, F. A., Vitamin Horm., 30, 45-82 (1972).

2 Marks, J., Vitamin Horm. 32, 131-i 54 (1974).

Otson, R.'E., Circulation, 48, 179-184 (1973).

4 Editorial, Lancet, i, 18 (1974).

Ratnoff, O. D., Adv. Immun., 10, 145-227(1969)

6 Kay, J. H., Hutton, S. B., Jr, Weiss, G. N., and Ochsner, A., Surgery, 28, 24-28

Korsan-Bengtsen, K. Elmfeldt

(Stuttg.), 31, 505-512(1974).

8 Moroz, L. A., and Gilmore, N. J., Blood, 46, 543-553 (1975).

9 Deutsch, D. G., and Mertz, E. T., Science, 170, 1095-1096(1970).

11 Brockway, W. J., and Castellino, F. J., Archs Biochem., 151, 194-199(1972). 240,541-550(1965).

12 Lambertsen, G., and Braekkan, O., Analyst, 84, 706-711 (1959).

13 Lambertsen, G., and Braekkan, O., Analyst, 84, 706-711(1959).

14 Robbins, K. C., and Summaria, L., Ann. N.Y. Acad. Sci., 209, $397-404$ (1973).

15 Zobbins, K. C., and Summaria, L., Ann. N. . A. J. Physiol., 153, 127-132 (1948)

16 Miller, W. H., and Dessert, A. M., Ann. N.Y. Acad. Sci, 52, 167-179 (1949)

17 Lassen, M., Acta Physiol. scand., 27, 371-376 (1952).

18 Oski, F. A., and Barness, L. A., J. Pediat., 70, 211-220(1967).

19 Rabiner, S. F., Goldfine, I. D., Hart, A., Summaria, L., and Robbins, K. C. J. lab. clin. Med., 74, 265-273(1969),

20 Sherry, S., A. Rev. Med., 19, 247-268(1968).

21 Magoon, E. H., Austen, K. F., and Spragg, J., Clin. exp. Immun., 17, 345-359

(1974).
22 Evans, H. M., and Bishop, K. S., J.metab. Res., 1. 319-356(1922).

Schreiber, A. D., Kaplan, A. P., and Austen, K. F., J. clin. Invest., 52, 1394-1401 (1973).

24 Clifton, E. E. Fedn Proc., 25, 89-93 (1966).

25 Telford, 1. R., Ann. N.Y. Acad. Sci, 52, 132-134 (1949).

\section{Confusion between specific and nonspecific binding of carcinoembryonic antigen and blood-group antigens by eluted antibody preparations}

Cross reactivity between carcinoembryonic antigen (CEA) and blood-group antigens is inferred from the observation that many human sera can bind labelled CEA. This is more common with sera of blood group $\mathrm{O}$ or $\mathrm{B}$ (that is containing anti-A antibodies), and binding may sometimes be inhibited by absorption of the sera with group $A$ erythrocytes ${ }^{1,2}$.

Following up these observations, Holburn et al. ${ }^{3}$ showed that hyperimmune human antisera against $A, B, L^{\star}$ and $\mathrm{Le}^{\mathrm{b}}$ antigens could bind $30-75 \%$ of added labelled CEA. They concluded that the extent of binding suggested that both CEA and blood-group antigens were present on the same molecule. Freedman, commenting on these experiments, pointed out that a hyperimmune antiserum will contain many other "sticky" substances as well as antibodies, and these might account for the results (paper read at meeting of British Society for Immunology, autumn, 


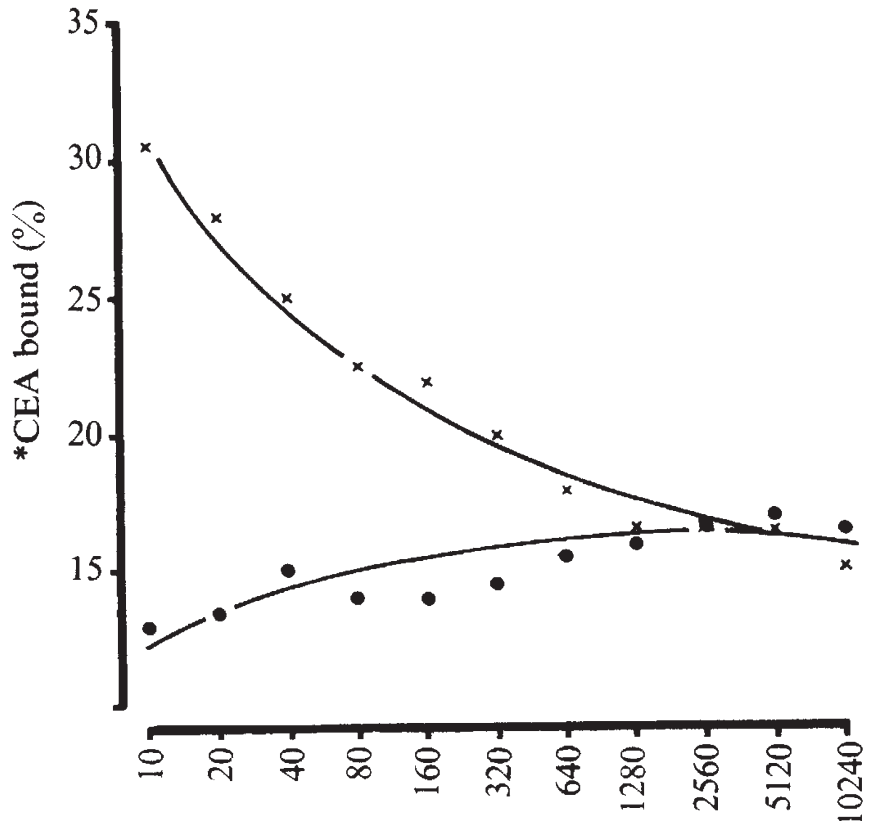

Serum dilution

Fig. 1 Binding of untreated anti-A $(\times)$ and anti-B $(0)$ to labelled * CEA, using Farr technique for separation.

1973). To exclude any extraneous binding substances his group in Montreal used "natural" anti-A iso-antibodies, which were adsorbed on to group A erythrocytes and eluted therefrom before use. Such antibody preparations could bind at least $45 \%$ of added labelled CEA as judged by the Farr technique ${ }^{1}$ and at least $11 \%$ as judged by a solid-phase technique ${ }^{4}$. We have now found that rather than removing nonspecific binding capacity from antisera, the process of adsorption to red cells and elution may increase it.

A preparation of CEA, given by Professor A. M. Neville, Chester Beatty Institute, was labelled with ${ }^{125} \mathrm{I}$ by the chloramine $\mathrm{T}$ method $^{5}$. Human anti-A and anti-B sera were obtained from Ortho Diagnostics (lots Pearl 02N0143 and Sally $11 \mathrm{M} 1219$, respectively). Samples of $60 \mathrm{ml}$ of each were decomplemented at $56{ }^{\circ} \mathrm{C}$ for $30 \mathrm{~min}$ and added to $10 \mathrm{ml}$ of washed packed fresh human erythrocytes; anti-A with A cells, anti-B with B cells. After overnight incubation at $4{ }^{\circ} \mathrm{C}$, with gentle mixing, the massively agglutinated cells were washed three times with large volumes of cold $0.9 \%$ saline. They were then mixed with an equal volume of $20 \%$ bovine serum albumin in saline and gently agitated in a water bath at $56{ }^{\circ} \mathrm{C}$ for $10 \mathrm{~min}$ to elute the bound antibodies. The supernates were tested by haemagglutination to confirm the presence and specificity of the antibodies.

Each solution was then divided into three equal portions; one to be absorbed overnight at $4{ }^{\circ} \mathrm{C}$ with $10 \mathrm{ml}$ washed packed A erythrocytes, one for similar absorption with group $\mathbf{B}$ erythrocytes and one to remain unabsorbed. The cells used for adsorption-elution and for absorption were taken from the same units of blood. Six solutions thus resulted: (1) eluted anti-A antibodies unabsorbed; (2) eluted anti-A antibodies absorbed with group A cells; (3) eluted anti-A antibodies absorbed with group B cells; (4) eluted anti-B antibodies unabsorbed; (5) eluted anti-B antibodies absorbed with group A cells; (6) eluted anti-B antibodies absorbed with group B cells.

The original anti-A and anti-B sera were used, without treatment, as further controls. Haemagglutination tests for antibody in all solutions demonstrated the presence and absence of the expected specificities.

All sera were titrated against labelled CEA, the separation system being half-saturation with ammonium sulphate in the presence of $0.5 \mathrm{ml}$ of $0.1 \%$ bovine gamma globulin. The experiment was repeated on three occasions with the same results.

Figures 1 and 2 show that fresh untreated anti-A can bind at least $30 \%$ of the CEA $(16 \%$ of the binding is nonspecific) while untreated anti-B has no significant activity - if anything, binding is slightly inhibited at a high concentration of serum. After adsorption and elution, all antibody solutions bind CEA to the same extent, irrespective of any subsequent absorption.

It might be argued that the Farr technique (halfsaturation with ammonium sulphate) is an inappropriate separation method for this experiment, since a constant $10-20 \%$ of CEA itself is precipitated, without any antiserum, in the presence of a 'carrier' protein (in this case,

Fig. 2 Binding of adsorbed-eluted anti-A and anti-B to labelled CEA, using Farr technique for separation. $a: \nabla$, Anti-A absorbed with $A$ cells; $\times$, anti-A absorbed with $B$ cellis; $\boldsymbol{\theta}$, anti-A unabsorbed. $b$ : + , anti-B unabsorbed: $O$, anti-B absorbed with A cells; $\nabla$, anti-B absorbed with B cells.

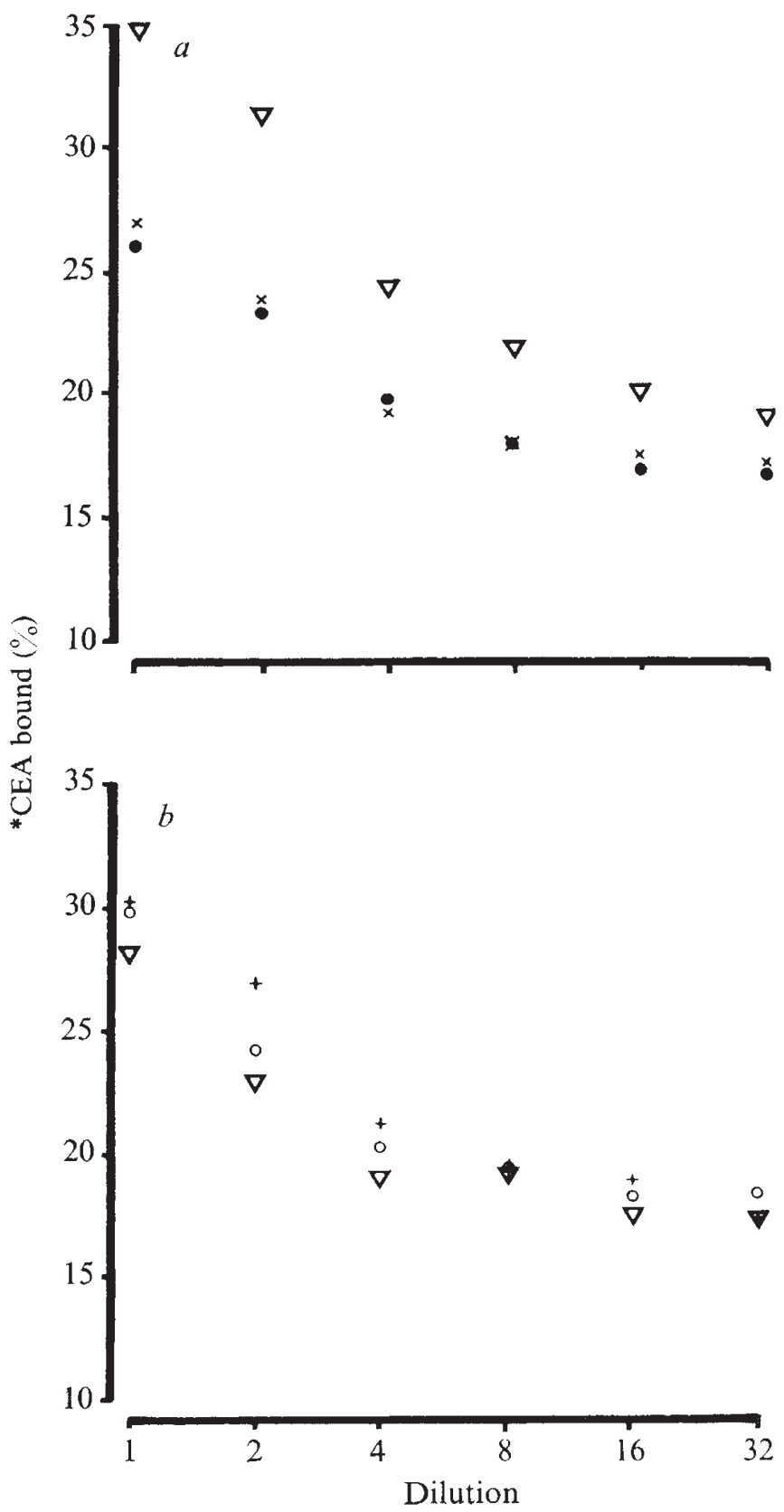



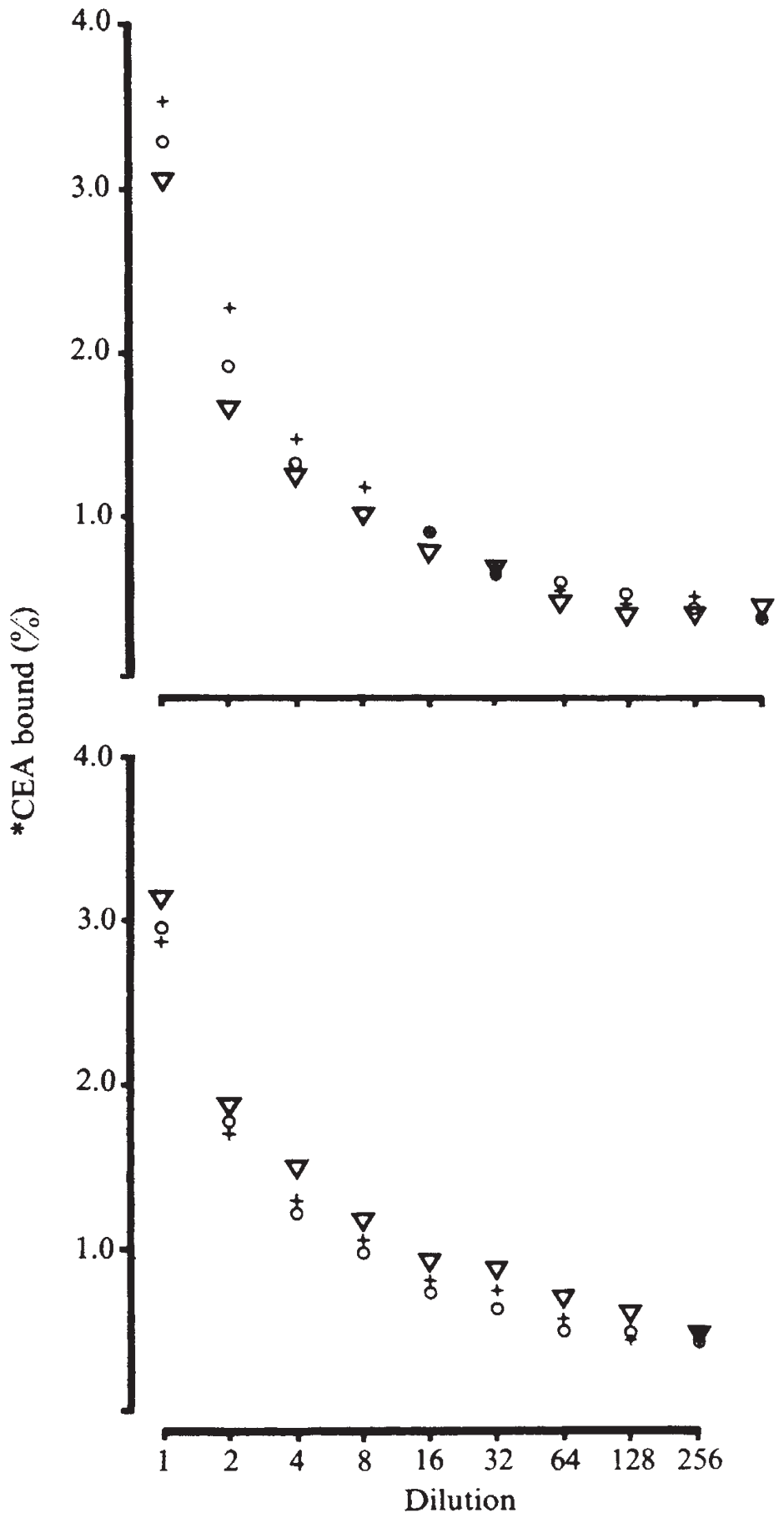

Fig. 3 Binding of adsorbed-eluted anti-A and anti-B to labelled CEA, using insoluble antibody preparations. $a$ : + Anti-A unabsorbed; $O$, anti-A absorbed with B cells; $\nabla$, anti-A absorbed with $\mathrm{A}$ cells. $b$ : + , anti-B absorbed with $\mathrm{B}$ cells; $\mathrm{O}$, anti-B absorbed with A cells: $\nabla$, anti-B unabsorbed.

bovine gamma globulin). Separation is therefore not clean and changes in binding capacity of the sera might be hidden. To answer this criticism, the six eluted antibody solutions were precipitated by $18 \%$ sodium sulphate and the globulins linked to microcrystalline cellulose (SigmaCell type 20) using the cyanogen bromide method ${ }^{6}$. The immunosorbents thus made were titrated against labelled CEA. Figure 3 shows that again there is no essential difference between absorbed and unabsorbed eluates.

These results show that adsorption and elution of anti-A from group A red cells makes no difference to its ability to bind CEA, thus confirming the results of Gold et al. ${ }^{1,4}$ On the other hand, absorption of this anti-A-containing eluate with group A red cells fails to reduce the binding capacity although its anti-A content becomes undetectable. This indicates that the CEA binding capacity of the eluate is not due to its anti-A activity. This conclusion is further supported by the development of CEA-binding capacity, previously absent, when anti-B is eluted from $\mathbf{B}$ cells. Again, this binding is not influenced by further absorption with either A or B cells.

The most likely interpretation is that human erythrocytes contain a 'sticky' non-antibody substance, extractable by heat elution, not removable by absorption with erythrocytes, which can bind to CEA. This may be the explanation for the finding ${ }^{7}$ that plasma which had been stored in contact with its cells had a higher apparent CEA level than the same specimen when fresh, and the subsequent finding ${ }^{\mathrm{B}}$ that a CEA-like substance could be extracted from erythrocyte stromata. It must be remembered that the double antibody technique which was used would register a CEA-binding substance as if it were CEA.

The results reported here also throw doubt on the existence of cross reactivity between CEA and blood-group substances, since they discredit the use of erythrocyteeluted antibodies for binding studies. Several reports favour such a negative view: (1) a monospecific anti-CEA serum does not agglutinate group A erythrocytes, and bloodgroup substances $\mathrm{A}$ and $\mathrm{B}$ do not inhibit CEA-anti CEA binding $^{1}$; (2) $N$-acetyl-D-galactosamine, the immunodominant sugar of $\mathbf{A}$ antigen, is conspicuously absent from most CEA preparations; ${ }^{4}$ (3) treating CEA with anti-A and anti-i immunosorbents causes no reduction in its CEA activity ${ }^{9}$; and (4) although the blood-group precursors I and $i$ can be found in extracts of colonic cancers, they can be separated from CEA by gel filtration ${ }^{10}$.

An alternative explanation is suggested by the association of CEA with mucus and the mucous coats of cells, both neoplastic and normal (to be published). One of the most striking physical properties of mucus is its cohesiveness. A CEA-binding substance is exuded by colonic cancer cells in tissue culture ${ }^{2}$, and such cells are also known to exude CEA into the medium (as judged by techniques which do not confuse CEA-binding substances with $\mathbf{C E A}^{11}$ ). Erythrocytes possess a mucous coat which they shed into the plasma as they become aged ${ }^{12}$. We would suggest that both CEA and CEA-binding substance reside in mucus and in the mucous coats of cells, though not necessarily on the same molecule.

We thank Mrs P. Standart, Mr T. W. Dutton and Miss A. Davies for technical assistance. This work was supported by a grant from the MRC.

\section{GEOFFREY TAYLOR}

Immunology Laboratory,

University of Manchester,

Manchester M13 9PT, UK

Received October 17; accepted November 27, 1975.

1 Gold, J. M., Freedman, S. O., and Gold, P., Nature new Biol., 239, 60-62 (1972). 2 MacSween, J. M., Int. J. Cancer, 15, 246-252 (1975)

Holburn, A. M., Mach, J-P., MacDonald, D., and Newlands, M., Immunology, 26, 831-843 (1974)

Gold, J. M., Banjo, C., Freedman, S. O., and Gold, P., J. Immun., 111, 1872-1879 (1973).

Hunter, W. M., Br. med. Bull, 30, 18-23 (1974).

Hart, I. C., J. Endocr., 55, 51-62 (1972).

Laurence, D. J. R., et al., Br. med.J., 3, 605-609 (1972).

Nery, R., Bullman, H., and Barsoum, A. L., Nature new Biol 246, 44-46, (1973). Cooper, A. G., Brown, M. C., Kirch, M. E., and Rule, A. H., J. Immun., 113 1246-1251 (1974)

C

11 Goldenberg. D. M., Pavia, R. A., and Hansen, H. J., Nature new Biol., 239, 189-190 (1972).

12 Cook, G. M. W., and Stoddart, R. W., Surface Carbohydrates of Eukaryotic Cells, 70 (Academic, London, 1973). 